PROFESI (Profesional Islam): Media Publikasi Penelitian

2019; Volume 16; No 2.

Website: ejournal.stikespku.ac.id

\title{
Tingkat Pengetahuan Kader Posyandu Tentang Difteri di Bakulan Cepogo Boyolali
}

\author{
Isnani Nurhayati ${ }^{1^{*}}$, Tri Yuniarti ${ }^{2}$ \\ 1,2DIII Keperawatan, STIKES Mamba'ul'Ulum Surakarta \\ *Email: isna@stikesmus.ac.id
}

\begin{abstract}
Kata Kunci
Kader,

Pengetahuan,

Difteri
\end{abstract}

\begin{abstract}
Abstrak
Sebanyak 593 kasus Difteri di bulan Januari hingga November 2017, tersebar di 95 kabupaten dan kota di 20 provinsi, dengan angka kematian 32 kasus. Didapatkan data 89\% Kader posyandu masih tidak tau tentang penyakit tersebut, dimana kader posyandu salah satu orang terpenting yang berpengaruh di masyarakat, khususnya di posyandu. Tujuan Penelitian: Mengetahui tingkat pengetahuan kader posyandu sebelum dan setelah dilakukan penddikan kesehatan tentang difteri di Bakulan, Cepogo, Boyolali Tahun 2017. Metode: Desain penelitian berupa diskriptif analitik dengan rancangan pretest-post test dalam satu grup (One-Group Pre Test-postest Design). Populasi dalam penelitian ini menggunakan total sample yaitu seluruh kader posyandu sebanyak 40 orang. Alat pengumpul data dengan kuesioner tertutup dengan skala Likert. Untuk menguji hipotesis ada tidaknya perbedaan rata-rata skor hasil tes kesetaraan kelompok dengan uji Paired Samples Test. Hasil: Tingkat pengetahuan responden sebelum pendidikan kesehatan pengetahuan baik 15 orang 37,5\%, cukup 23 orang 57,5\%,dan kurang 2 orang 5\%. Tingkat pengetahuan responden setalah pendidikan kesehatan pengetahuan baik 23 orang 37,5\% dan cukup 17 orang 42,5\%. Hasil Uji statistik Paired Simple T Tes Nilai responden sebelum dan setelah diberi pendidikan kesehatan Diketahui nilai signifikasinya sebesar 0,000 ( $<$ dari 0,05), maka kesimpulannya ada perbedaan nilai tes sebelum dan sesudah dilakukan pendidikan kesehatan tentang difteri. Diketahui $t$ hitung adalah -4,182, dan $t$ tabelnya 2,023. Jikaa -t hitung < -t tabel $(-4,182<-2,023)$ maka $H_{0}$ ditolak. Ada perbedaan nilai dan setelah dilakukan pendidikan kesehatan, yaitu nilai pengetahuan responden meningkat tentang penyakit difteri.
\end{abstract}

\section{The Knowledge Level of Posyandu Cadres About Diphtheria in Bakulan Cepogo Boyolali}

Key Words:

Kader,

Knowledge, Difteri

\section{Abstract}

The Ministry of Health showed up to November 2017, 95 districts and cities from 20 provinces reported diphtheria cases. At bakulan Village there were 10 posyandu both toddlers and elderly, and 40 active cadres and 89\% cadre had poor knowledge about diphtheria. The research method used is Analytical Descriptive with pretest-post test in one group (One-Group Pre Test-posttest Design). This study carried out preliminary observations (pre test) and final observations (post test). This research was analytic descriptive with Cross Sectional approach. The population was all posyandu cadres, sampling techniques with a total sampling of 40 respondents. The data analysed using Paired Simple T Test. The results of the study There is increasing knowledge of Posyandu cadres between before and after health education. Based on the results of Paired Simple T Test, it is known that the correlation value is 0.486 with a significance of 0.000 , because the significance is $<0.05$, it can be concluded that there is a significant correlation between the values before and after health education on Diphtheria. There are differences in test scores before and after health education on diphtheria. It is interpreted by the existence of health education the level of respondents' knowledge about Diphtheria increasing 


\section{PENDAHULUAN}

Jumlah penderita Difteri bulan Januari hingga November 2017 sebanyak 593 oanag, tersebar di 95 kabupaten dan kota di 20 provinsi, dengan angka kematian 32 kasus. Data World Health Organization (WHO) tentang penyakit difteri menunjukkan jumlah kasus difteri di Indonesia naik turun sejak 1980-an. Data Kementerian Kesehatan menujukkan sampai dengan November 2017, ada 95 kabupaten dan kota dari 20 provinsi yang melaporkan kasus Difteri. Secara keseluruhan terdapat 622 kasus, 32 diantaranya meninggal dunia. Bulan Oktober hingga November 2017, ada 11 Provinsi yang melaporkan terjadinya KLB difteri, antara lain di Sumatra Barat, Jawa Tengah, Aceh, Sumatra Selatan, Sulawesi Selatan, Kalimantan Timur, Riau, Banten, DKI Jakarta, Jawa Barat dan Jawa Timur (Kementrian Kesehatan RI 2017)

Rentang waktu bulan Januari hingga Desember 2017, kasus KLB Difteri di Indonesia terhitung yang terbesar di dunia. Populasi penduduk di Indonesia yang menderita penyakit Difteri disebut memang paling banyak jika dibandingkan negara yang pernah terjangkit wabah yang sama.

Difteri lebih sering menyerang anak-anak usia di bawah 12 tahun dan lebih berdampak fatal dari pada menyerang orang dewasa. Karena usia anak sistim kekebalan tubuhnya belum terbentuk dengan maksimal. Difteri merupakan penyakit infeksi yang mudah menular dan berbahaya karena dapat menyebabkan kematian. Kuman difteri masuk dalam tubuh melalui kontak langsung dengan orang terinfeksi atau barang terkontaminasi. Bakteri ini mengikuti aliran sistemik dalam tubuh, inkubasi pada tubuh 2 sampai 5 hari, terus mengeluarkan toksin atau racun (Depkes, 2011).

Pola hidup bersih dan sehatpun sangatlah penting dilakukan dalam kehidupan sehari-hari guna mencagah timbulya berbagai macam penyakit. Peningkatan pengetahuan tentang difteri diharapkan mampu meminimalkan munculnya penyakit menular maupun tidak menular. Peran orang tua dalam mencegah timbulnya penyakit baik di dalam rumah maupun diluar rumah menjadi pondisi bagi anak-anaknya maupun lingkungan sekitarnya.

Sarana prasarana yang ada di sekitar masyarakat khususnya pelayanan kesehatan diharapakan mampu membantu menangani kasus sedini mungkin. Peran serta kader kesehatan yang sangat dekat dengan masyarakat dapat memaksimalkan pegetahuan tentang kesehatan yang dapat disampaikan pada ibu balita.

Desa Jetis Karangpung yang memiliki 10 posyandu baik balita maupun lansia, dan 40 kader yang aktif, dengan jumlah balita sekitar 240 balita yang ada di desa tersebut. Cakupan imunisasi $100 \%$ sudah dilaksanakan oleh pihak Puskesmas Cepogo, salah satunya adalah imuniasi DPT (Defteri Pertusis dan Tetanus). Penyakit defteri sampai saat ini tidak diderita oleh balita tersebut, namun tingkat pengetahuan orang tua (ibu) dan Kader posyandu terhadap Defteri sangatlah kurang. Di dapatkan data $89 \%$ Kader posyandu masih tidak tau tentang penyakit tersebut, dimana kader posyandu salah satu orang terpenting yang berpengaruh di masyarakat, khususnya di posyandu.

Tujuan penelitian ini untuk mengetahui tingkat pendidikan sebelum diberi pendidikan kesehatan tentang difteri, mengetahui tingkat pendidikan setelah diberi pendidikan kesehatan tentang difteri dan menganalisa hubungan sebelum dan setelah dilakukan penddikan kesehatan tentang difteri dengan hipotesa dalam penelitian inin adalah adakah perbedaan pengetahuan sebelum dan sesudah dilakukan pendidikan kesehatan tentang Difteri.

\section{METODE PENELITIAN}

Desain penelitian yang digunakan adalah Diskriptif Analitik dengan rancangan pretest-post test dalam satu grup (One-Group Pre Test-postest Design). Penelitian ini dilakukan observasi awal (pre tes) dan observasi akhir (post tes). Ciri dari tipe penelitian ini adalah mengungkapkan hubungan sebab akibat dengan cara melibatkan satu kelompok subyek. Penlitian ini diberi perlakukan dengan memberikan pendidikan kesehatan pada responden tentang penyakit Diferi.

Definisi operasional adalah mendefinisiakan variabel secara operasional berdasarkan karak- 
PROFESI (Profesional Islam): Media Publikasi Penelitian

2019; Volume 16; No 2.

Website: ejournal.stikespku.ac.id

teristik yang diamati, sehingga memungkinkan peneliti melakukan observasi atau pengukuran secara cermat terhadap obyek atau fenomenal.

Definisi operasional dalam penelitian ini sebagai berikut: Tingkat pendidikan kader posyandu adalah pendidikan yang diperoleh ibu dari pendidikan formal Alat ukur berupa Kuesioner, Kategori: Dasar (SD - SMP), Mengengah (SMA) dan Perguruan Tinggi (Ihsan, 2010). Lama menjadi Kader adalah mulai awal bergabung menjadi kader posyandu samapai saat ini. Alat ukur: menggunakan kuesioner dengan kategori: 1 - 5 tahun, 5 - 10 tahun dan lebih 10 tahun.

Tingkat pengetahuan adalah segala sesuatu yang diketahui oleh kader posyandu tentang penyakit Difteri. Alat ukur: Kuesioner. Kategori: Baik skor > 80\%, Cukup 60-80 \%, Kurang < 60 $\%$ (Ihsan, 2001).

Usia adalah waktu manusia mulai lahir sampai saat penelitian Alat ukur: waktu. Kategori: 17 - 25 tahun: Remaja Akhir, 26 - 35 tahun: Dewasa awal, 36 - 45 tahun: Dewasa akhir, 46 - 55 tahun: Lansia awal 56 - 66 tahun: lansia akhir (Depkes, 2009). Populasi dalam penelitian ini adalah seluruh kader posyandu di Desa Bakulan Kecamatan Cepogo Kabupaten Boyolali sebanyak 40 orang.sekaligus menjadi sampel Teknik pengambilan sampel pada penelitian ini adalah dengan menggunakan total sampling, yaitu teknik menentukan sampel dengan mengambil seluruh populasi sebagai responden atau sampel. Jumlah kader 4o orang sehingga dijadikan responden semua. Alat pengumpul data dengan kuesioner tertutup dengan skala Likert. Untuk menguji hipotesis ada tidaknya perbedaan rata-rata skor hasil tes kesetaraan kelompok dengan uji Paired Samples Test.

Analisa Univariat meliputi: umur, jenis kelamin, tingkat pendidikan, pekerjaan, distribusi frekuensi sebelum dan setelah di lakukuan eksperimen pada responden. Analisa Bivariat dilakukan terhadap dua variabel yang diduga berhubungan atau berkorelasi. Penelitian ini menggunakan metode analitik sampel kecil kurang dari 50 maka uji normalitias data menggunakan uji shapiro-wilk dengan ketentuan nilai keyakinan yang dipakai adalah 0,95 dan nilai kemaknaan 0,05. Untuk melihat distribusi data normal atau tidak dengan cara, jika $p$ value >
0,05 maka distribusi data normal dan apabila $p$ value $<0,05$ maka distribusi data tidak normal.

Untuk menguji hipotesis ada tidaknya perbedaan rata-rata skor hasil tes kesetaraan kelompok dengan uji Paired Samples Test untuk data yang berdistribusi, dimana kriteria pengujian yang digunakan jika t-hitung > t-tabel pada derajat keabsahan n-2 dan taraf signifikansi 5\%, maka kelompok dinyatakan ada perbedaan yang signifikan. Berdasarkan hasil ini diketahui apakah hipotesa yang diajukan diterima atau tidak dengan ketentuan nilai keyakinan yang dipakai adalah 0,95 dan nilai kemaknaan $\alpha=0,05$. Jika $p$ value $<\alpha$, maka Ho ditolak, artinya ada perbedaan pengetahuan tentang penyakit Difteri sebelum dan sesudah dilakukan pendidikan kesehatan.

\section{HASIL DAN PEMBAHASAN}

Analisa Univariat dilakukan untuk menggambarkan karakteristik dari responden, meliputi:

a. Data Tingkat Pendidikan Responden Posyandu

Tabel 1. Tingkat Pendidikan Responden

\begin{tabular}{lcc}
\hline Pendidikan & Frekuensi & $\%$ \\
\hline PT & 9 & 18 \\
SMA & 14 & 35 \\
SMP & 13 & 32,5 \\
SD & 13 & 32,5 \\
Total & 40 & 100 \\
\hline
\end{tabular}

Pada tabel.1 menunjukan bahwa jumlah responden sebanyak 40, tingkat pendidikan SD $32,5 \%$, SMP $23,5 \%$ dan SMA $35 \%$

b. Data Tingkat Pengetahuan

Tingkat pengetahuan responden tentang difteri sebelum diberi penyuluhan kesehatan

Tabel 2. Tingkat Pengetahuan Responden Sebelum Intervensi

\begin{tabular}{ccc}
\hline Pengetahuan & Frekuensi & $\%$ \\
\hline Baik & 15 & 37,5 \\
Cukup & 23 & 57,5 \\
Kurang & 2 & 5 \\
Total & 40 & 100 \\
\hline
\end{tabular}


PROFESI (Profesional Islam): Media Publikasi Penelitian 2019; Volume 16; No 2.

Website: ejournal.stikespku.ac.id

Pada tabel 2. Menunjukkan bahwa jumlah responden sebanyak 40 sebelmu dilakukan intervensi, pengetahuan baik 15 orang $37,5 \%$, cukup 23 orang $57,5 \%$, dan kurang 2 orang $5 \%$

c. Hasil tabulasi data tingkat pengetahuan responden tentang difteri setelah diberi penyuluhan kesehatan

Tabel 3. Tingkat Pengetahuan Responden Posyandu Setelah Intervensi

\begin{tabular}{lrr}
\hline Pengetahuan & Frekuensi & $\%$ \\
\hline Baik & 23 & 57,5 \\
Cukup & 17 & 42,5 \\
Kurang & 0 & 0 \\
Total & 40 & 100 \\
\hline
\end{tabular}

Pada tabel 3. Menunjukkan bahwa jumlah responden sebanyak 40 setelah dilakukan intervensi, pengetahuan baik 23 orang 57,5\%, cukup 17 orang $42,5 \%$.

d. Umur Responden

Tabel 4. Umur Responden

\begin{tabular}{ccc}
\hline Umur & Frekuensi & $\%$ \\
\hline $17-25$ & 1 & 2,5 \\
$26-35$ & 3 & 7,5 \\
$36-45$ & 16 & 40 \\
$46-55$ & 10 & 25 \\
$56-65$ & 10 & 25 \\
Total & 40 & $100 \%$ \\
\hline
\end{tabular}

Sumber: Data primer 2017

Tabel 4. Menunjukkan umur responden paling banyak adalah 36 sampai dengan 45 tahun dengan jumlah 16 orang atau $40 \%$ dari total reponden.

e. Lama Menjadi Kader Posyandu

Tabel 5. Lama Menjadi Responden Posyandu

\begin{tabular}{lrr}
\hline Lama menjadi kader & Frekuensi & $\%$ \\
\hline 1 s/d 5 tahun & 11 & 27,5 \\
6 s/d 10 tahun & 23 & 57,5 \\
$>10$ tahun & 6 & 15 \\
Total & 40 & 100 \\
\hline
\end{tabular}

Pada tabel 4.4 Lama kader menjadi kader posyandu sebagian besar $6 \mathrm{~s} / \mathrm{d} 10$ tahun 23 responden $(57,5 \%)$.

\section{Analisa Bivariat}

Tabel 6. Tingkat Pengetahuan Responden Sebelum dan Setelah Dilakukan Pendidikan Kesehatan

\begin{tabular}{|c|c|c|c|c|}
\hline Tingkat pengeth & Mean & $\mathrm{n}$ & $\begin{array}{c}\text { Std. } \\
\text { Deviation }\end{array}$ & $\begin{array}{l}\text { Std. } \\
\text { Error } \\
\text { Mean }\end{array}$ \\
\hline $\begin{array}{l}\text { Sblm } \\
\text { Pendkes }\end{array}$ & 76,98 & 40 & 9,007 & 1,424 \\
\hline $\begin{array}{ll}\text { Pair Ith } & \text { Stlh } \\
& \text { Pendkes }\end{array}$ & 82,81 & 40 & 8,352 & 1,321 \\
\hline
\end{tabular}

Tabel 7. Hasil Uji Statistik dengan Simple Paired t Tes

\begin{tabular}{llccc}
\hline & & N & $\begin{array}{c}\text { Correl } \\
\text { ation }\end{array}$ & Sig. \\
\hline Pair 1 & $\begin{array}{l}\text { Seblm Pendkes \& } \\
\text { Stl Pendkes }\end{array}$ & 40 &, 486 &, 001 \\
\hline
\end{tabular}

Berdasarkan tabel 7, diketahui nilai korelasi 0,486 dengan signifikansi 0,000 , karena signifikansi $<0,05$ maka dapat disimpulkan terjadi hubungan yang signifikan antara nilai sebelum dan setelah dilakukan pendidikan kesehatan tentang Difteri. Nilai sebelum dan setelah dilakukan pendidikan kesehatan tentang Difteri. Diketahui nilai signifikasinya sebesar 0,000 (< dari 0,05), maka kesimpulannya ada perbedaan nilai tes sebelum dan sesudah dilakukan pendidikan kesehatan tentang difteri. D iketahui $\mathrm{t}$ hitung adalah 4,182 , dan $\mathrm{t}$ tabelnya 2,023 . Jikaa $-\mathrm{t}$ hitung < $\mathrm{t}$ tabel $(-4,182<-2,023)$ maka $\mathrm{H}_{0}$ ditolak. Sehingga disimpulkan ada perbedaan nilai antara sebelum dilakukan pendidikan kesehatan dan setelah dilakukan pendidikan kesehatan, yaitu pengetahuan responden meningkat tentang penyakit difteri. Dapat diartikan dengan adanya pendidikan kesehatan tingkat pengetahun responden tentang Difteri meningkat. 
PROFESI (Profesional Islam): Media Publikasi Penelitian 2019; Volume 16; No 2.

Website: ejournal.stikespku.ac.id

Tingkat pengetahuan responden tentang difteri sebelum dilakukan penyuluhan kesehatan.

Pengetahuan merupakan hasil dari tahu, yang terjadi setelah seseorang melakukan penginderaan terhadap suatu objek tertentu melalui panca indra manusia (Notoatmojo, 2010)

Tabel 2 menunjukkan bahwa jumlah responden sebanyak 40, pengetahuan baik 15 orang $37,5 \%$, cukup 23 orang 57,5\%,dan kurang 2 orang $5 \%$. Tingkat pengetahuan responden tentang difteri sebelum dilakukan pendidikan kesehatan adalah hal-hal yang diketahui oleh responden tentang Difteri berdasarkan kemampuan yang dimiliki dalam menjawab pertanyaan pada koesioner (Listyowati, 2012)

Tingkat pengetahuan responden tentang difteri setelah dilakukan pendidikan kesehatan. Hasil penelitian tingkat pengetahuan responden posyandu jumlah responden sebanyak 40, pengetahuan baik 23 orang $37,5 \%$ dan cukup 17 orang $42,5 \%$. Tingkat pengetahuan responden tentang difteri setelah dilakukan pendidikan kesehatan adalah halhal yang diketahui oleh responden tentang Difteri berdasarkan kemampuan yang dimiliki dalam menjawab pertanyaan pada koesioner setelah dilakukan pendidikan kesehatan tentang Difteri (Listyowati, 2012).

Berdasarkan hasil penelitian menunjukkan bahwa adanya peningkatan pengetahuan responden kesehatan antara sebelum dan setelah dilakukan pendidikan kesehatan. Berdasarkan hasil uji Paired Simple T Tes diketahui nilai korelasi 0,486 dengan signifikansi 0,000, karena signifikansi $<0,05$ maka dapat disimpukan terjadi hubungan yang signifikan antara nilai sebelum dan setelah dilakukan pendidikan kesehatan tentang Difteri.

Tingkat pengetahuan responden terhadap penyakit difteri sebelum dilakukan pendidikan kesehatan rata-rata cukup dengan prosentase 23 orang $(57,5 \%)$, setelah dilakukan pendidikan kesehatan tingkat pengetahuan responden meningkat rata-rata dengan kategori baik berjumlah 23 orang (57,5\%). Peningkatan pengetahuan responden dari kategori cukup ke kategori baik antara sebelum dan setelah dilakukan Tingkat pengetahuan responden ini meningkat dari kategori cukup ke kategori baik. Peningkatan ini didukung dari tingkat pendidikan responden yang rata-rata tingkat pendidikannya SMA 35\%. Seseorang yang memiliki pendidikan baik akan cenderung mencari tahu tentang informasi, semakin tinggi pendidikan seseorang makin mudah orang tersebut menerima informasi Potter \& Perry (2006). Penyampaian pendididkan kesehatan tentang difteri juga salah satu yang berpengaruh terhadap peningkatan pengetahuan responden.

Peningkatan pengetahuan diartikan sebagai hasil dari penyuluhan kesehatan dengan menggunakan media audiovisual dan film pendek tentang proses terjadinya penyakit Difteri namun diimbangai pengalaman menjadi kader dan seringnya kader ini berperan atif setip acara yang diselenggarakan oleh pihak Puskesmas maupun Kelurah, seperti pada tabel 4.4 dimana lama kader menjdi kader posyandu rata-rata $6 \mathrm{~s} / \mathrm{d} 10$ tahun sebanyak 23 responden $(57,5 \%)$. Seringnya responden ini berkegiatan Merangsang otak mereka untuk berfikir secara atif dan mampu memberi solusi jika ada permasalahn terkait dengan kegiatannya. Pemberian informasi melalui pendidikan dan pelatihan akan meningkatkan pengetahuan, selanjutnya akan menimbulkan kesadaran dan akhirnya akan melakukan tindakan sesuai dengan pengetahuan yang dimiliki meskipun memerlukan waktu yang lama.

Hal ini sejalan dengan yang diungkapkan oleh Notoatmojo (2010) bahwa tujuan penyuluhan adalah adanya peningkatan pengetahuan masyarakat dibidang kesehatan, tercapainya perubahan perilaku individu, keluarga dan masyarakat sebagai sasaran utama penyuluhan kesehatan dalam membina perilaku masyarakat dan lingkugan serta berperan aktif dalam upaya peningkatan derajat kesehatan yang optimal sesuai dengan konsep sehat sehingga dapat menurunkan angka kesakitan dan kematian.

Peningkatan pengetahuan yang dialami oleh responden melalui proses ataupun tahapan. Seperti yang dikemukakan oleh Murti (2018) individu mengalami peroses perubahan yang bersifat kognitif, afektif dan psikomotor. 
PROFESI (Profesional Islam): Media Publikasi Penelitian 2019; Volume 16; No 2.

Website: ejournal.stikespku.ac.id

Pada tahap ini responden pada proses perubahan secara kognitif atau pengetahuan dimana responden diberi informasi melalui penyuluhan tentang penyakit difteri. Harapannya setelah diberi info tentang difteri mereka dapat menyampaikan pada ibu balita, lansia dan warga masyarakat untuk mencegah secara dini timbulnya penyakit difteri. Salah satu faktor penngkatan pengetahuan adalah bantuan media yang meanarik berupa media LCD proyektor dan disertai teyangan gambar dan film sehingga responden memperhatikan saat diberikan penjelasan. Hal ini seperti yang diungkapkan oleh Hamidah (2012) yang menyatakan bahwa media dalam proses pembelajaran akan menyebabkan proses pembelajaran menjadi menarik perhatian responden sehingga dapat mudah difahami dan sasaran tidakcepat bosan.

Penelitian ini sejalan dengan Warto (2013) yang meneliti tentang pegaruh pendidikan kesehatan tentang pengendalian vektor penyakit PES terhadap tingkat pengetahuan dan sikap warga dalam upaya pencegahan penyakit PES di Desa Jrakah Boyolali sebelum dan setelah dilakukan pendididkan kesehatan.

Hasil Uji statistik Paired Simple T Tes Nilai responden sebelum dan setelah diberi pendidikan kesehatan. Diketahui nilai signifikasinya sebesar 0,000 (< dari 0,05), maka kesimpulannya ada perbedaan nilai tes sebelum dan sesudah dilakukan pendidikan kesehatan tentang difteri. $\mathrm{D}$ iketahui $\mathrm{t}$ hitung adalah $-4,182$, dan $t$ tabelnya 2,023. Jikaa $-\mathrm{t}$ hitung < - t tabel $(-4,182<-2,023)$ maka $\mathrm{H}_{0}$ ditolak. Sehingga disimpulkan ada perbedaan nilai antara sebelum dilakukan pendidikan kesehatan dan setelah dilakukan pendidikan kesehatan, yaitu nilai pengetahuan responden meningkat tentang penyakit difteri. Dapat diartikan dengan adanya pendidikan kesehatan tingkat pengetahun responden tentang Difteri meningkat.

Hasil penelitian ini sama dengan penelitian Aditya (2016) yang menyatakan ada hubungan yang signifikan antara sebelum dan setelah dilakukan pendidikan keshatan tentang deteksi dini kasus difteri anak $(\mathrm{p}=0,001)$.

Hasil penelitian menunjukkan bahwa telah terjadi penambahan pengetahuan atau peningkatan nilai seperti yang diharpkan dalam penelitian. Peningkatan pengetahuan ini karena adanya pemberian informasi dimana didalamnya terdapat proses belajar.

\section{SIMPULAN}

Hasil penelitian menunjukkan adanya peningkatan pengetahuan responden kesehatan antara sebelum dan setelah dilakukan pendidikan kesehatan. Berdasarkan hasil uji Paired Simple T Tes disimpukan terjadi hubungan yang signifikan antara nilai sebelum dan setelah dilakukan pendidikan kesehatan tentang Difteri. Terdapat perbedaan nilai tes sebelum dan sesudah dilakukan pendidikan kesehatan tentang difteri diartikan dengan adanya pendidikan kesehatan tingkat pengetahun responden tentang Difteri meningkat.

Saran dari peneliti. Untuk Kader Posyandu adalah dapat ikut berperan aktif dalam upaya peningkatan kesehtan balita dengan memberikan informasi yang benar pada keluarga dan masyarakat tentang Penyakit Difteri baik diposyandu, pertemuan warga maupun ditempat umum. Untuk Puskesmas setempat dapat Bekerjasama dengan Pemeritah untuk menurunkan angka kesakitan yang disebabkan karena Difteri dengen memberikan edukasi tentang Penyakit Difteri dan Untuk Profesi Kesehatan ; Bersama keluarga, kader dan masyarakat melakukan tindakan pencegahan penyakit Difteri melalui promosi kesehatan

\section{REFERENSI}

Aditya. (2016). Data dan Metode Pengumpulan Data Penelitian. Surakarta: Poltekes Kemenkes Surakarta.

Asfar. (2018). Pengaruh Penyuluhan Kesehatan terhadap Tingkat Pengetahuan dan Sikap tentang Penyakit HIV/AIDS di SMP BAZNA Propensi Sulawesi Selatan. journal.uin-alauddin.ac.id/index.php/. 25 April 2018 (11:40)

Departemen Kesehatan RI. (2009). Kategori Usia.https://yhantiaritra.wordpress.com/

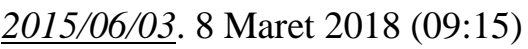


PROFESI (Profesional Islam): Media Publikasi Penelitian 2019; Volume 16; No 2.

Website: ejournal.stikespku.ac.id

Departemen kesehatan RI. (2010). Penanganan Penyakit Difteri di Indonesia. Jakarta: Depkes RI

Departemen Kesehatan RI. (2011). Penanganan Defteri. Jakarta: Depkes RI

Departemen Kesehatan RI. (2014). Profil Kesehatan Kabupaten Boyolali. www. depkes.go.id/recouces/kab.Boyolali. 8 Desember 2017 (09:40)

Ihasan, F. (2010). Filsafat Ilmu. Jakarta: Rineka Cipta

Kementrian Kesehatan RI. (2017). Difeteri. www.denkes.go.id. 20 Nopember 2017 $(14: 15)$

Kementrian Kesehatan RI. (2017). Defteri Menular dan Berbahaya. http://www. depkes.go.id/article/view/17121200002. 21 April 2018 (12:30)

Listyowati. (2012). Pengaruh Intervensi Promosi Kesehatan terhadap Pengetahuan, sikap dan Perilaku Cuci Tangan pada siswa SD kelas V di SD Pangasinan V. Skripsi. Universitas Indonesia.Bekasi
Murti, B. (2018). Teori Promosi dan Perilaku Kesehatan. Jawa Tengah: Bintang Fajar Offset

Notoatmojo, S. (2010) ${ }^{\mathrm{a}}$. Metodologi Penelitian Kesehatan. Jakarta: Rineka Cipta

Notoatmojo, S. (2010) $)^{\mathrm{b}}$. Ilmu perilaku kesehatan. Jakarta: Rineka Cipta

Warto. (2013). Pegaruh pendidikan kesehatan tentang pengendalian vektor penyakit PES terhadap tingkat pengetahuan dan sikap warga dalam upaya pencegahan penyakit PES di Desa Jrakah Boyolali sebelum dan setelah dilakukan pendididkan kesehatan. Skripsi. Universitas Muhammadiyah Surakarta. Surakarta

Wirawan. (2014). Penyuluhan dengan Media Audio Visual dan Konvensional terhadap pengetahuan ibu dan bayi. https:// journal. unnes.ac.id/nju/index.php/emas/. 8 Maret 2018 (10:25) 